\title{
Article
}

\section{Does non-employment contribute to the health disadvantage among lone mothers in Britain, Italy and Sweden? Synergy effects and the meaning of family policy.}

Fritzell, Sara, Vannoni, Francesca, Whitehead, Margaret, Burstom, Bo, Costa, Giuseppe, Clayton, Stephen and Fritzell, Johan

Available at http://clok.uclan.ac.uk/10703/

Fritzell, Sara, Vannoni, Francesca, Whitehead, Margaret, Burstom, Bo, Costa, Giuseppe, Clayton, Stephen ORCID: 0000-0003-2823-1495 and Fritzell, Johan (2012) Does non-employment contribute to the health disadvantage among lone mothers in Britain, Italy and Sweden? Synergy effects and the meaning of family policy. Health \& Place, 18 (2). pp. 199-208.

It is advisable to refer to the publisher's version if you intend to cite from the work. http://dx.doi.org/10.1016/j.healthplace.2011.09.007

For more information about UCLan's research in this area go to http://www.uclan.ac.uk/researchgroups/ and search for <name of research Group>.

For information about Research generally at UCLan please go to http://www.uclan.ac.uk/research/

All outputs in CLoK are protected by Intellectual Property Rights law, including Copyright law. Copyright, IPR and Moral Rights for the works on this site are retained by the individual authors and/or other copyright owners. Terms and conditions for use of this material are defined in the policies page. 
Elsevier Editorial System(tm) for Health \& Place

Manuscript Draft

Manuscript Number: JHAP-D-10-00433R2

Title: Is non-employment associated with the health disadvantage among lone mothers in Britain, Italy and Sweden? Family policy and synergy effects

Article Type: Full Paper

Keywords: Single parent; welfare state; family policy; poor health; employment

Corresponding Author: Ms Sara Fritzell,

Corresponding Author's Institution: Karolinska Institute

First Author: Sara Fritzell

Order of Authors: Sara Fritzell; Francesca Vannoni; Margaret Whitehead; Bo Burström; Giuseppe Costa; Stephen Clayton; Johan Fritzell

Manuscript Region of Origin: Other European (everywhere in Europe apart from UK)

Abstract: This study analyses self-rated health and non-employment and potential synergy effects among lone and couple mothers aged 25-59 in Britain, Sweden and Italy, representing different family policy categories using data from national surveys (2000-2005). Synergy effects on health were calculated by synergy index. Non-employment only marginally contributed to the excess risk of poor health among lone mothers but there were synergy effects between lone motherhood and nonemployment in all three countries, producing a higher risk of poor health than would be expected from a simple addition of these exposures. Results are discussed in relation to the different family policy and living contexts. 
Responses to reviewer \# 3's comments:

- The title would read better if "contribute to" is replaced by "associated with". Consider also omitting the subtitle.

Response: We have changed the title accordingly, and altered the subtitle. The new title reads: "Is non-employment associated with the health disadvantage among lone mothers in Britain, Italy and Sweden? Family policy and synergy effects"

- Avoid causal arguments and terminology throughout the text ("causal", "impact", "effect" etc.).

Response: We have searched the text for causal arguments and terminology, and changed the wording where we thought it appropriate, and kept the wording when referring to other studies where this terminology has been used.

- Use "employment" instead of "work" wherever appropriate.

Response: We have gone through the article and change wherever appropriate.

- The country specific analyses have been separately conducted and therefore avoid direct comparisons of countries in terms of the levels of risk (OR). Interactions would be needed for direct country comparisons.

Response: We agree and have made alterations in the text.

- The second para of Discussion says "Non-employment only partly explained.". In my mind the explanation was minimal.

Response: We agree and have changed this to: "Non-employment only marginally contributed to the excess risk...." 


\title{
Is non-employment associated with the health disadvantage among lone mothers in Britain, Italy and Sweden? Family policy and synergy effects
}

\author{
Outline manuscript \\ Please do not quote or cite
}

\begin{abstract}
This study analyses self-rated health and non-employment and potential synergy effects among lone and couple mothers aged 25-59 in Britain, Sweden and Italy, representing different family policy categories using data from national surveys (2000-2005). Synergy effects on health were calculated by synergy index. Non-employment only marginally contributed to the excess risk of poor health among lone mothers but there were synergy effects between lone motherhood and non-employment in all three countries, producing a higher risk of poor health than would be expected from a simple addition of these exposures. Results are discussed in relation to the different family policy and living contexts.
\end{abstract}

\section{Key words:}

Single parent, welfare state, family policy, poor health, employment

\section{Introduction}

Combating poverty and increasing the standard of living among disadvantaged groups is a basic purpose of developed welfare states. Lone mothers, being an economically vulnerable group of women, have been proposed as a litmus test as to how family policy regimes operate (Burstrom, Whitehead et al. 2010). This article builds on our previous study of health inequalities between lone and couple mothers in different family policy regimes (Burstrom, Whitehead et al. 2010), and adds sub-group analysis of a particularly vulnerable group of the lone mothers; the non-employed.

As Bambra and Eikemo (2009) recently showed, the associations between employment status and health play out differently in different countries. Several studies have found positive health effects of combining employment and family for women, including lone mothers 
(Fokkema 2002; Lahelma, Arber et al. 2002; Artazcoz, Borrell et al. 2004; Zabkiewicz 2010). Ferrie et al. 2006), and with negative health behaviours such as smoking (Waldron and Lye 1989), women who are keeping house full time are more likely to report ill health, compared to those in employment (Bartley, Ferrie et al. 2006). Studies have shown that there may be health selection into non-employment (Jusot, Khlat et al. 2008).

However, the relation between employment and health may be different among men and women, in different social groups, and in different national contexts, where the meaning of paid employment may vary because of norms, values and policies. Family policy encompasses policies for reconciling employment and parenthood (Gornick and Meyers 2003). These are of particular salience to parents with dependent children, and especially for lone mothers. Labour market opportunities for women vary between different welfare systems and by social groups, and these country differences are further related to family policy. For example, in countries with "earner-carer" (dual earner) policies, employment rates are higher among women with low or medium education than in countries with "market-oriented" and "traditional-family" policies (Korpi, Ferrarini and Englund 2011).

Drawing specific examples of distinctive family policy categories from the Korpi et al typology, we analyse country level data from countries where we have in depth knowledge of the policy framework and living conditions among lone mothers. In this study, we aim to compare health and non-employment experiences of lone and couple mothers in different social positions in Britain, Sweden and Italy. We analyse empirically the social characteristics and composition of lone motherhood, exposures to non-employment, the association between non-employment and health and calculations of synergy effects between non-employment and lone motherhood on health. Finally we discuss the observed findings in relation to policy and living conditions for lone mothers in each country. As there are relatively few lone fathers in our datasets and both the explanations for poor health and the employment policy context are likely to differ for men and women, we have not included lone fathers in the study presented here, but they are the subject of future studies.

Model of family policy, parenting and working in Britain, Italy and Sweden 
As arrangements differ widely between countries, various welfare state typologies have been proposed, including the most recent models based on institutional structures of relevance for both gender inequality and class inequality that take special account of the expansion of family policy and its effects on the lives of women (Korpi 2000; Ferrarini 2006; Lundberg, Åberg Yngwe, et al 2008; Ferrarini and Norström 2010). Family policies are multidimensional and reflect conflicting political forces as well as religion. The main distinction is made by whether they favour traditional families, market reliance or mother's employment. This typology groups countries similarly to the well-known overall welfare typology of Esping-Andersen (1990). The difference however, is that the focus here solely is on institutional dimensions of family policy.

Figure I illustrates the categorisation of family policy along two dimensions: the degree to which policy supports a traditional, nuclear family (where benefits, tax relief and leave entitlements support the father as the main breadwinner and the mother to stay at home to care for children) and the degree to which policy supports a dual-earner family. The exact operationalization of the model is spelled out in detail in Ferrarini and Norström (2010). The categorisation of countries should not be regarded as fixed, but may change as policy shifts. Below we discuss what outcomes the institutional differences in family policy have in terms of arrangements for employment and parenting for mothers in our chosen countries. 


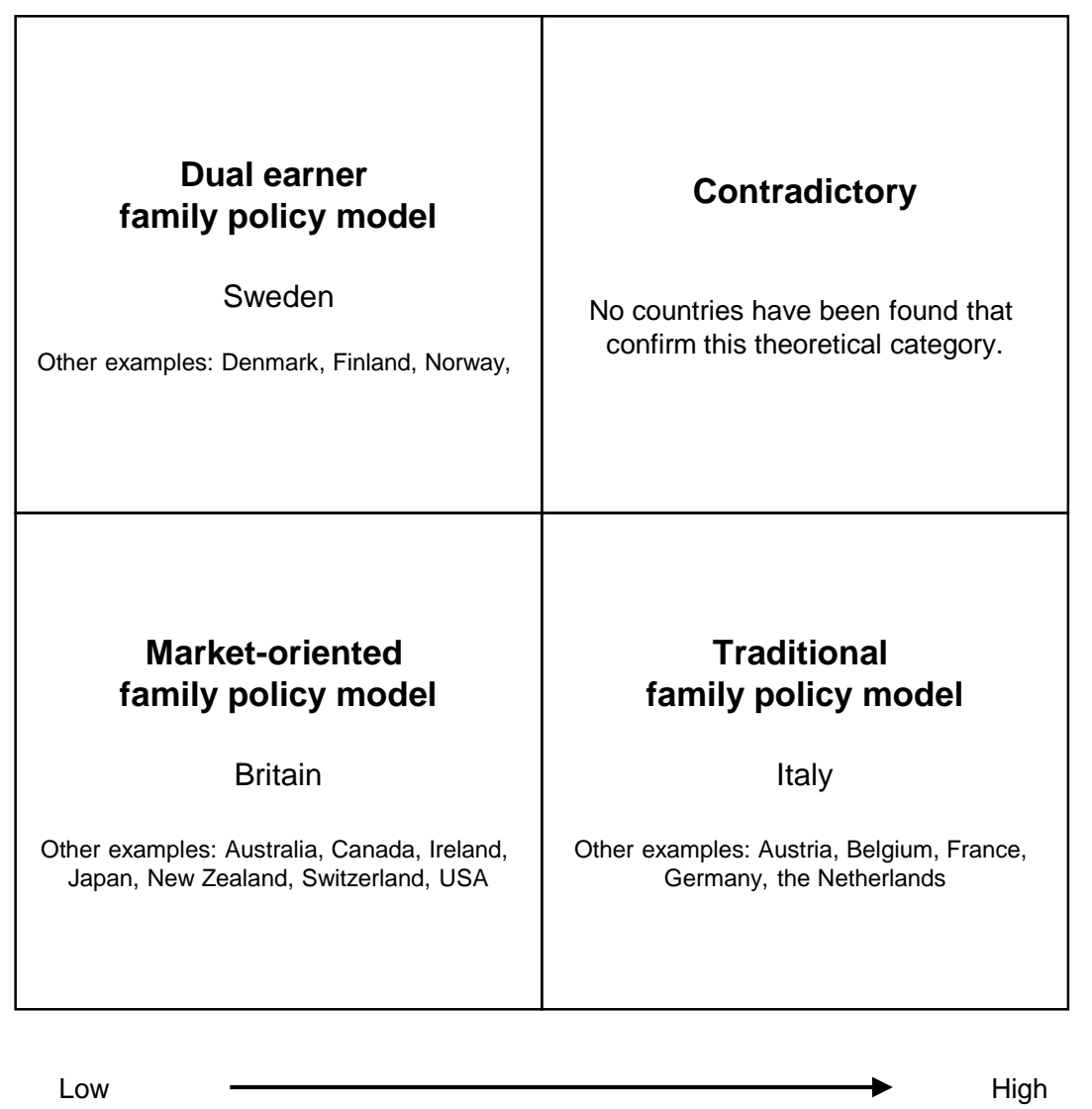

Support to highly gendered divisions of labour

Figure I. Dimensions and models of family policy around the year 2000. Adapted from Korpi 2000, Ferrarini 2006 and Ferrarini and Norström 2010

In this typology, Britain falls into the 'Market-oriented model' with lower levels of support in both dimensions, leaving families to deal with family support and childcare privately through the market. Traditionally, employment rates have been low among mothers in Britain, especially among lone mothers, who have received financial support to stay at home with their children. Since the late 1990s and until recently, however, a range of social and employment policies have been introduced to support maternal employment (Cebulla, Flore et al. 2008; Lewis, Knijn et al. 2008) and these efforts have increased employment rates of lone mothers. Flexible employment and family friendly policies have been introduced through legislation and both maternal and paternal leave and benefits have been improved albeit from a comparatively low level (La Valle, Clery et al. 2008). At the same time, there was extensive investment in making childcare more available and affordable, with the National Childcare Strategy introducing 15 hour per week of free early years education for three and four year olds and a subsidy for childcare for working low and middle income families (La Valle, Clery 
et al. 2008). Child care for children aged below three is generally provided by parents, positive effect on lone mothers employment (Gregg, Harkness et al. 2009), the limited provision of low-cost, flexible childcare for low income parents, and lone mothers in particular, remains a barrier to employment (Finch 2008; LaValle and Smith 2009).

Italy falls into the 'Traditional family policy model', orientated towards preserving traditional family patterns with highly gendered divisions of labour within families. Tax benefits for a working male with a dependent partner and flat-rate childcare leave benefits encourage mothers to stay at home. Family and relatives are expected to provide support and the welfare state has only a residual role to tackle very critical situations, when individuals and families are poor in a manifest way and are entitled to become public assistance recipients. Negative attitudes towards mothers' employment are more prevalent than in the other policy categories (Korpi 2000). As in the rest of southern Europe, women tend either not to work at all, or work full-time and continuously, and lone mothers are often in the latter category (Orloff 2002; Sabbadini 2006). Childcare in Italy is generally high in quality, but availability is limited and heterogeneous across regions, and offers low flexibility in hours of service (Del Boca and Vuri 2007). Family support is thus necessary, and the availability of informal childcare increases the probability of mothers' employment (Del Boca and Vuri 2007). It is especially common that grandmothers mind children aged below three, for whom child care is not readily available (Naldini and Saraceno 2008). The downside to informal childcare is family dependency for lone mothers (Solera 1998).

Sweden falls into the 'Dual-earner model', encouraging both fathers and mothers to work through family-friendly employment policies (including generous parental leave and possibilities to reduce work hours) and subsidized universal pre-school childcare provision. The employment rates of mothers including lone mothers' in Sweden are thus among the highest in Europe. However, the employment rate among lone mothers has declined during the last decade. Childcare in Sweden is generally considered to be of high quality and affordable, fees are income related (with a low ceiling) and heavily subsidised and available full time from the child's first birthday (Ferrarini and Duvander 2010). Recent changes in family policy includes the implementation of the "daddy-months" in the parental leave system, but also a flat rate home care allowance that allows a parent to stay home and tend to small children and receive a relatively low monthly allowance for this (Ferrarini and 
Duvander 2010). These observed differences between the countries might suggest that the relationship between lone motherhood, non-employment and health might vary.

\section{Lone motherhood, non-employment and health}

Lone motherhood is associated with worse health in all three countries (Burstrom, Whitehead et al. 2010). Three main pathways to ill health have been proposed in the literature: material, behavioral and psychosocial pathways (Marmot 2006). Discussing how non-employment may be related to poor health among lone mothers, the material aspect is important. Studies have shown that household labour market attachment has become increasingly important for alleviating poverty risks (Fritzell and Ritakallio 2010). In many welfare systems, employment also generates eligibility for welfare resources. Being non-employed could result in poverty, which may affect health in several ways. Besides the direct effect of material scarcity, the alienation from society and stigma also affect health (Reid and Tom 2006). This relates to the psychosocial pathway.

As noted by many researchers, life styles and health behaviours such as smoking, lack of exercise, poor nutrition etc. are strongly linked to social position, and as such are more prevalent among persons with low education and the unemployed and among lone mothers in some countries. Non-employment in this study is regarded as a potential explanatory factor in the association between lone motherhood and poor health. As noted, mothers' employment rates vary between the countries. There are many reasons for women's economic inactivity, which may also differ between countries. A study analysing women's disconnection from the labour market in England showed that (excluding students) this group included: full time homemakers; retired people; those who are not in employment because of long term illness or disability; and those who were seeking employment but were not available for work in the next two weeks (Grant 2009). Of those who are economically inactive, there may be a large proportion who want to work, but who are restrained from doing so (Grant 2009). We also distinguish a group that is economically active but not employed; the unemployed. The "nonemployed' category is therefore made up of three main groups: people of working age who are available for employment and actively seeking employment but without jobs, labelled 'unemployed'; people of working age who are not available for employment and not seeking it due to a variety of reasons: for example permanent sickness, early retirement, students in education, labelled 'economically inactive'. A specific sub-group within the 'economically 
inactive' category are singled out for separate analysis and these are homemakers; people of

Aim

This study analyses the relationship between non-employment and health among lone and couple mothers in three different family policy models. Furthermore, we investigate whether there are synergy effects between being a lone mother and non-employed on health in these different settings, and discuss the results related to policy and actual living conditions.

\section{Data and methods}

\section{Datasets}

National surveys based on a representative random sample of the population were used for analyses for each policy setting, identifying lone and couple mothers aged 25-59 years. For Britain we analysed data from the General Household Survey (GHS) (Office for National Statistics 2002). The GHS is a continuous, cross-sectional survey of household in Britain, administered by face-to face interviews to all adults aged 16 and over in the selected households. Data were pooled for the years 2000-2003, yielding 1573 lone and 5293 couple mothers. The response rate was between 67 and $72 \%$. For Italy we used data from the National Health Survey for the years 1999-2000 (Istat 2002) and 2004-2005 (Istat 2007), administered by both face-to-face interviews and self-complied questionnaires, on a sample representative of the non-institutionalised population. We identified 4031 lone and 38841 couple mothers. The response rate was 87 and $84 \%$ respectively. For Sweden we analysed data from the Swedish Survey of Living Conditions (ULF), conducted by Statistics Sweden (Statistics Sweden 2006). The ULF is a continuous series of annual surveys on the welfare of the population, administered by face-to-face interviews, which draws a random sample of approximately 7,500 people from all permanent residents in Sweden, aged between 16 and 84 
years. Data for the years 2000-2005 were pooled, 867 lone and 4260 couple mothers were identified. The response rate was between 75 and $78 \%$.

\section{Independent variable definitions}

A mother was defined as a person who lives with at least one of her children aged less than 18 years. A "couple" mother was defined as a mother who is either married or cohabiting and lives with her partner. A "lone" mother may or may not be living with other adults in the households but does not live with a partner.

Age was divided into age groups: 25-34, 35-44 and 45-59.

Level of education was classified based on the international standard classification of education (ISCED) for highest attained level of education (UNESCO 1997). The national codes were classified into three categories using the ISCED-scheme. ISCED levels 1 and 2 were grouped into "low education", levels 3 and 4 into" medium education" and levels 5 and 6 into "high education".

Occupational class is based on current or last occupation, and respondents were classified into three groups; "non-manual", "manual" and "never worked". The last group includes mothers who could not be classified into any of the other groups.

Employment status was classified into "employed" (including mothers who are employed part time/full time or work unknown hours or are self-employed), "unemployed" according to the ILO definition (unemployment is a count of jobless people who want to work, are available to work, and are actively seeking work) and "economically inactive" (all others). Mothers looking after the home were classified as "homemakers", and were analysed separately from the economically inactive as they make up a large share of mothers in Britain and Italy. Swedish lone homemakers were few (n below 50), and therefore included in the economically inactive category. In the multivariate analyses (see table II and III), "nonemployed" refers to all those not in employment.

Having pre-school children may influence employment decisions for both lone and couple mothers, and perhaps more so for lone mothers. If there is no available/affordable childcare 
working outside the home may be difficult. The definition of pre-school children was country-specific, according to the common age of starting school. For Britain this means children under the age of five, for Italy under the age of six and for Sweden children under the age of seven years.

Although not the focus of this study, we have included smoking, as an important health behaviour that is implicated in explanation of the observed social inequalities in health (Jarvis and Wardle 2006). Smoking status was coded as daily smoker vs not daily smoker.

\section{Dependent variable}

The outcome measure was self-rated health (SRH). SRH is recommended as a health indicator by WHO (Lundberg, Manderbacka et al. 2000) and is considered a good proxy of future morbidity and mortality (Benjamins, Hummer et al. 2004, Jylhä 2009). SRH has been shown to be useful both for use within countries and in country comparisons (Lundberg and Manderbacka 1996; Jylhä, Guralnik et al. 1998; Yngwe, Diderichsen et al. 2001). In British data, SRH was measured on a three-point scale, ranging from "good" to "not good". The responses were dichotomized as "good" and "poor health" (comprising fair and not good health). In Italian, as well as in Swedish data, SRH was measured using a five-point scale ranging from "very good" health to "very poor" health. The responses were dichotomized into "good health"(comprising very good and good health) and "poor health" (comprising average, poor and very poor health). All mothers with a missing value on SRH were excluded from analyses.

\section{Statistical analysis}

Population characteristics of lone and couple mothers were calculated for each country using national survey data. Multivariate logistic regression models were fitted to evaluate the relationship between motherhood type and employment status, with poor health as outcome measure. In the first model we adjusted for age group. The second model additionally adjusted for education. Using educational level rather than current or last occupation as a measure for socio economic position in the regression model was judged as preferable since education precedes employment. The third model also adjusted for employment status. The fourth model adjusted for age group and daily smoking. The covariates included in the final 
model were motherhood type (lone $=1$ versus couple mother $=0$ ), age (dummies of age groups; 25-34, 35-44, 45-59, with the age group reporting best health among lone mothers as a reference in each country respectively, in all countries 25-34), level of education (dummies of education; low, medium and high, with high education as the reference category) employment status (non-employed $=1$ versus employed $=0$ ), smoking (daily smoker $=1$ versus not daily smoker=0). Since measures like SRH may be culturally biased (Jyhlä 2009) we studied the countries one by one, looking at the excess risk among lone mothers within countries (see Esser and Palme (2010) for a similar design). This is further motivated by the slight difference in how SRH was measured in Britain.

For Italian data, weights were used to handle differences in sample strategies between the survey years. Proportion coefficients were obtained dividing the sample weights of the two data sets (1999-2000 and 2004-2005) by the product of the sum of the sample weights for corresponding frequencies.

Interaction effects on health between being lone and non-employed were assessed using the synergy index, according to Rothman's definition of interaction (Rothman and Greenland 1998) using a SAS program developed by Lundberg, Fredlund, Hallquist and Diderichsen (Lundberg, Fredlund et al. 1996). The model investigates whether there are cases that only occur in the presence of joint exposure, i.e. the effect of one factor depends on the person's status of the other factor. Where there is departure from additivity of effects, the exposures may be dependent on one another. If the value for synergy exceeds 1.0 there is synergy.

The synergy index is given by:

$\mathrm{SI}=\left[\mathrm{RR}_{11}-1\right] /\left[\left(\mathrm{RR}_{10}-1\right)+\left(\mathrm{RR}_{01}-1\right)\right]$

$\mathrm{RR}_{11}$ is the relative risk (RR) among those who are exposed to both risk factors (here: nonemployment and lone motherhood), $\mathrm{RR}_{10}$ and $\mathrm{RR}_{01}$ are the relative risks where only one of the risk factors are present, respectively. $R_{00}$ is the reference category, which is equal to 1 . In this study, since we use cross-sectional data we use the odds ratio (OR) instead of RR. The results are obtained through logistic regression, controlling for age and level of education. The interaction analyses were made for lone and couple mothers who were non-employed vs. 
employed, economically inactive vs. employed, and finally unemployed vs. employed. We also stratified analyses of synergy index by presence of pre-school children in household.

SAS version 9.2 was used for statistical analyses. The study was approved by the Regional Ethics Committee in Stockholm, Dnr 2009/1046-31.

\section{Results}

Following the framework for studying pathways to inequalities in health from the social context to health outcomes (Diderichsen, Evans et al. 2001; Fritzell, Ringback Weitoft et al. 2007; Burstrom, Whitehead et al. 2010), we explored three principal explanations for health inequalities between non-employed lone and couple mothers; compositional factors, differential exposure to risk factors and finally, differential vulnerability to the same exposures.

Social characteristics and composition of lone motherhood and exposures to non-employment in Britain, Italy and Sweden

As presented in Table I, the composition of mothers varied between the countries. Lone motherhood was most common in Britain, where one in four mothers was lone. The median age of mothers and especially lone mothers was lowest in Britain (38 years for couple and 36 years for lone) and highest in Italy (42 years for couple and 46 years for lone). Swedish lone mothers were more evenly distributed across the age groups. Unemployment was more common among lone than couple mothers in all three countries. Being in the labour force, whether employed or unemployed, was most common among Swedish lone mothers $(77.4 \%)$ and least common among British lone mothers (60.8\%). Only in Italy did lone mothers have higher labour force participation than couple mothers. Homemakers were a large group in Britain, and more frequent among lone than couple mothers. In Italy the opposite pattern was found. The economically inactive category was more frequent among lone mothers in all three countries. 
In Italy, the largest relative differential in poor health between lone and couple mothers was

There were some similarities between the countries in the composition of mothers by employment and occupation. In all countries, the employed lone mothers were more often had higher education, were more often non-manual than manual workers, and reported better health than did non-employed lone mothers. Also, it was less common for lone mothers with pre-school children to be employed than for couple mothers in the same situation.

The non-employed lone mothers in both Britain and Sweden were more likely than employed lone mothers to be young and have pre-school children (especially the British homemakers). The pattern in Italy differed from that in Britain and Sweden. Italian lone mothers who were homemakers or other economically inactive were more often older, smoked less and reported worse health than the employed or unemployed. Many of the Italian homemakers were in the oldest age group and had never worked. British couple mothers who were homemakers were predominantly non-manual, while the lone were mainly manual, and more prevalent in the younger age-groups.

Daily smoking was more common among non-employed lone mothers in Britain and in Sweden, while the employed (and unemployed) lone mothers in Italy reported the highest rates of smoking. In Sweden and Britain it was nearly twice as common for lone than couple mothers to smoke daily.

\section{Table I about here}

Do differences in exposure to non-employment between lone and couple mothers explain the risk of poor health?

As there were differences in the social composition between the lone mothers who were employed and non-employed, we fitted logistic regression models modelling the odds of poor health for lone mothers compared to couple mothers, adjusting for these factors (see Table II). The regression analysis showed that the age adjusted odds ratios between motherhood type and poor health were highest in Sweden and lowest in Italy. Non-employment was indeed 
significantly associated with a higher risk of poor health in all settings (OR with CI in model 3; Britain 1.70 (1.52-1.90); Italy 1.13 (1.08-1.18); Sweden 2.22 (1.91-2.59). Being a smoker was also independently associated with poor health. However, differences in exposure to nonemployment between lone and couple mothers only marginally contributed to the excess risk of poor health among lone mothers.

\section{Table II about here}

Differential vulnerability- is it worse for health to be non-employed and a lone rather than a couple mother?

Lone mothers may be more vulnerable to non-employment in terms of health. In the interaction analyses (see Table III) we found examples of synergy effects, i.e. that there was an interaction effect of combining the exposures of being a lone mother and being nonemployed, causing a higher risk of poor health than would be expected from a simple addition of these exposures, in all three countries, although not statistically significant for British lone mothers.

\section{Table III about here}

Stratified analyses by presence of preschool children in the household, showed that the negative interaction effect for combining the exposures of being a lone mother and being outside the labour market was higher among British non-employed lone mothers with preschool children (2.33, CI 0.97-5.60) compared to 0.98 (CI 0.68-1.42) for lone mothers with older children. In Sweden the pattern was the opposite, SI for non-employed lone mothers with pre-school children was 1.60 (CI 0.83-3.11) and 2.45 (CI 1.46-4.11) for lone mothers with older children. Italian data showed that SI for non-employed lone mothers with older children was 1.73 (CI 1.02-2.92) (the model with preschool children did not converge due to low number of lone mothers with preschool children).

\section{Discussion}

Main results 
The prevalence, social composition and employment status of lone motherhood differed between the countries. Lone motherhood in both Britain and Sweden was associated with increased risk of poor health, while lone mothers in Italy did not have higher risk of poor health compared to couple mothers. Poor health was more prevalent among the non-employed mothers compared to those employed, in all countries.

Non-employment only marginally contributed to the excess risk of poor health among lone mothers found in Britain and Sweden. However, there were synergy effects for lone motherhood and non-employment, indicating a higher risk of poor health than would be expected from a simple addition of these exposures, in all countries. Patterns of synergy effects regarding lone mothers with pre-school children differed between the countries.

\section{Why increased risk of poor health among the non-employed lone mothers?}

The prevalence and age composition of lone mothers differed between the countries. The nonemployed in Britain and Italy differed greatly in age. While Britain has a large share of young mothers, in Italy many of the non-employed were homemakers who were generally older. Common to both groups is that they have difficulty in finding employment. The high employment rate in Sweden of women from all social groups is due both to the availability of childcare and the job opportunities in the large public service sector. Women's position in the labour market is affected by a range of social and labour market policies, not least by the provision of child care (Huber, Stephens et al. 2009). Indeed, as other studies have shown, having pre-school children (Gornick and Meyers 2003) and low education are both related to lower employment proportions among women (Lewis 2009). Looking specifically at mothers with pre-school children we found that the family policy context does have salience in the British and Swedish context, and appeared to be linked to the availability of child care. Thus, the risk of poor health was higher among British non-employed lone mothers with pre-school children (compared to having older children), while the pattern was the opposite for Swedish lone mothers. Combining employment and lone parenthood may be difficult due to the time strain it imposes, and lone mothers may be confined to non-employment in spite of a desire to work. Besides providing material resources, employment is an important aspect of motherhood, also in England (Grant 2009). In line with the dual earner family policy model, 
in Sweden, working is the morally right thing to do for mothers (Björnberg 1997, Fritzell, Bakshi et al. 2011). However, often the jobs available to lower educated women or (as in the case of Grant's study, 2009) women who are living in disadvantaged neighbourhoods, are low paid jobs that lack flexibility in working hours. This lack of flexibility in work hours, as well as lack of flexibility in availability of day care may prevent lone mothers from working (Fritzell, Bakshi et al. 2011).

Health behaviour may also explain part of the statistical association between lone motherhood, non-employment and health. Smoking was nearly twice as common among lone than couple mothers in Britain and Sweden, and most prevalent among the non-employed. In Italy, differences in smoking between lone and couple mothers were smaller, and the lowest rates were reported among the non-employed mothers. In the British context, smoking is strongly related to poverty and disadvantage (Graham 2007). Experiences of disadvantage such as childhood poverty, leaving school early, moving into early parenthood are cumulative and lead to an increased risk of being a smoker (Graham 2007). Also in Sweden, smoking is linked to adversity (Ali, Chaix et al. 2009). In Italy, by contrast, smoking has recently been taken up by women and is more common among the higher educated, but a shift is taking place among young women where smoking is more common among the less educated group (Federico, Costa et al. 2007).

The reasons for the synergy effects between lone motherhood and non-employment may be two-fold. Firstly, there is health selection into non-employment (Jusot, Khlat et al. 2008), and this may be especially so for lone mothers. Secondly, the health impact of not having an income from gainful employment may be especially damaging for lone mothers. Both of these, in turn, may vary with the societal context.

The welfare arrangements and family policy in Sweden are encompassing and comparatively generous. In spite of this, lone mothers without employment fare relatively worse in relation to other mothers in Sweden. This may imply a stronger health selection out of employment in Sweden compared to Britain, where the employment rate was lowest and where (lone) mothers have not been expected to work to the same extent. Employment may also have a different meaning and a different association to health in the three countries. While both Britain as part of the Market-oriented family policy model, and Italy as part of the Traditional-family policy model, have actively promoted mothers to stay at home and look 
after children - putting women with children apart from the rest of the workforce, in Sweden there is an employment imperative for all citizens alike. The findings concerning the poor health of the unemployed are in line with findings of Bambra and Eikemo (2009), who interpreted their finding as indicating that the negative health effects of unemployment are particularly strong for women in the Scandinavian and Anglo-Saxon welfare regimes (where we find Sweden and Britain respectively), in comparison with the Southern welfare states (where Italy is included). Our analyses focus on the "early days" of the policy changes in Britain that took place during the 1997-2010 Labour government aimed at facilitating employment for lone mothers. It will be important to follow up what effect these changes in policy context, have had for health and living conditions for lone mothers.

The health impact of not having an income from gainful employment may be especially damaging for lone mothers. Financial strain has been shown to be an important explanation for the excess risk of ill health of lone mothers in comparison to couple mothers (Hope, Power et al. 1999; Fritzell and Burström 2006; Cooper, Bebbington et al. 2008). Evidence from the Luxembourg Income Study (LIS Inequality and Poverty Key Figures 2010) 2004 and 2005 indicated that the poverty rates (below $50 \%$ of median income) are high among children living in lone mother families, and that they vary between the countries; for Britain $32.1 \%$, for Italy $29.8 \%$, and for Sweden $10.4 \%$. Additional analyses of European Social Survey (ESS) data (Survey 2009) from rounds 1 and 2 conducted between 2002 and 2006, indicated that financial problems were considerably more common among the non-employed lone mothers than among the employed in all three countries (data not shown). Furthermore, in terms of social exclusion, analyses from the ESS data show that the non-employed lone mothers stood out as more disadvantaged than employed lone mothers, and in relation to non-employed couple mothers. This is in line with the reasoning of Sen (2000) who argues that besides from being excluded from economic opportunities it may also be problematic for jobless people to participate in community life.

Swedish lone mothers have experienced a deterioration of living conditions and health during the 1990s. The link between employment and health has become stronger (Fritzell, Ringback Weitoft et al. 2007), and the present study shows that health was strongly associated with employment also in 2000-2005. Still, the comparatively low level of poverty among families with children in Sweden (and other Nordic countries) is likely to be due both to the relatively higher level of benefits received and the dual-earner model facilitating mothers' employment 
(Ferrarini 2006). Replacement rates and entitlements to benefits are of potential significance

Seemingly, in Italy there was only a small excess risk for less than good health compared to couple mothers. This may however be influenced by family values, social stratification and of different routes into lone motherhood. Mothers can be lone parents for many reasons. Family values regarding divorce, separation and unmarried parenthood in combination with possibilities of making a living as a lone mother - what Orloff (1993) calls "capacity to form an independent household" - influence the composition and the size of the group lone mothers. A previous study (Burstrom, Whitehead et al. 2010) showed that the most common route into lone motherhood in Italy was becoming a widow, while divorce/separation or being single from the start was by contrast the most common route in Sweden and Britain. In Italy, there are no unemployment benefits for those who have not yet entered the labour market, and there is no national last resort safety net for the poor (Naldini and Saraceno 2008). Accordingly, in Italy divorce and separation is most common among women with high social position; well educated women with attachment to the labour market (Solera 1998; Istat 2008; Burstrom, Whitehead et al. 2010) and only in Italy was employment more prevalent among lone mothers compared to couple mothers.

Researchers have argued that Italy is experiencing the emancipation of women resulting in an increase in the numbers of lone mothers (Trifiletti, Pratesi et al. 2001). Should the anticipated development continue and the composition change to include all social groups, it may result in increased differentials in health between lone and couple mothers in Italy, and in particular among the youngest and lowest skilled/educated mothers who are known to be disproportionately hit by unemployment. As Korpi, Ferrarini and Englund (2011) note, it is the women with working class background that are at higher risk of non-employment in all types of family policy dimensions. Women with higher education are in the labour force to a larger extent irrespective of family policies, as seen in this study particularly in the case of Italian lone mothers. The dual earner family policy model however does better in including other social groups in the labour market, as seen in the Swedish employment proportions for mothers. 


\section{Limitations}

The cross sectional design of this study does not allow for conclusions on the causality of the associations we find. We used large national household surveys, pooling several survey years to yield statistical power and enable sub group analysis of the non-employed. Data comparability is a potential pitfall in all cross-national research. Issues concerning sample frame and country specific variables may limit the comparability between countries using national surveys. We were not able to analyse financial problems or lack of social support for all three countries, known to be prevalent risk factors among the non-employed lone mothers. Analysing data on national level may also conceal regional differences, for instance labour market participation for mothers varies from $60 \%$ in the northern areas to $20 \%$ in the southern areas of Italy (Del Boca and Vuri 2007). Levels of, as well as entitlements to, transfers also differ between regions in Italy.

As the response rate is generally lower among those with lower socio-economic position, and in poor health status are less likely to participate in surveys (Lorant, Demarest et al. 2007), it is possible that the excess risk of less than good health among non-employed lone mothers is underestimated in this study.

Reporting of levels of self-rated health may be culture specific. These differences may be real differences in objective health status, or differences in levels of knowledge that underlie selfrated health or finally differences in how personal evaluations of health are made (Jyhlä 2009). The absolute prevalence levels of poor health, therefore, were not compared between countries. Comparing sub-groups within countries, we may use the absolute prevalence rates. Large relative differences between lone and couple mothers within each employment status group were found in Sweden. The large relative inequalities as well as the comparatively low absolute levels of poor health found in Sweden are consistent with other studies (Lahelma and Lundberg 2009).

Although causality cannot be inferred, this study suggests potential explanations behind the poor health of the non-employed and identifies non-employment as a structural issue with implications for lone mothers' health.

\section{Conclusion}


Being non-employed was relatively worse for lone than couple mothers' health, in all three countries studied. Lone motherhood and non-employment are dynamic states. From a public health perspective, this makes the poor health of non-employed lone mothers all the more important as it affects many women and their children, and potentially increasingly so, since lone motherhood is an increasing phenomenon. Theoretically, it could be remedied as family policy is shaped by politics. Further work would benefit from a specific focus on lone fathers. 


\section{References}

Ali, S. M., B. Chaix, et al. (2009). "Gender differences in daily smoking prevalence in different age strata: A population-based study in southern Sweden." Scandinavian Journal of Public Health 37(2): 146-152.

Artazcoz, L., C. Borrell, et al. (2004). "Women, family demands and health: the importance of employment status and socio-economic position." Soc Sci Med 59(2): 263-274.

Bambra, C. and T. A. Eikemo (2009). "Welfare state regimes, unemployment and health: a comparative study of the relationship between unemployment and self-reported health in 23 European countries." J Epidemiol Community Health 63(2): 92-98.

Bartley, M., J. Ferrie, et al. (2006). Health and labour market disadvantage: unemployment, non-employment, and job insecurity. Social determinants of health. M. Marmot and R. G. Wilkinson. Oxford Oxford University Press: 78-96.

Benjamins, M. R., R. A. Hummer, et al. (2004). "Self-reported health and adult mortality risk: an analysis of cause-specific mortality." Soc Sci Med 59(6): 1297-1306.

Björnberg, U. (1997). Single Mothers in Sweden: Supported Workers who Mother. Single Mothers in an International Context. Duncan S, Edwards R. London, UCL Press: 24167.

Burstrom, B., M. Whitehead, et al. (2010). "Health inequalities between lone and couple mothers and policy under different welfare regimes - the example of Italy, Sweden and Britain." Soc Sci Med 70(6): 912-920.

Cebulla, A., G. Flore, et al. (2008). The New Deal for Lone Parents, Lone Parent Work Focused Interviews and Working Families' Tax Credit: A review of impacts. London.

Cooper, C., P. E. Bebbington, et al. (2008). "Depression and common mental disorders in lone parents: results of the 2000 National Psychiatric Morbidity Survey." Psychol Med 38(3): 335-342.

Del Boca, D. and D. Vuri (2007). "The mismatch between employment and child care in Italy: the impact of rationing." Journal of Population Economics 20(4): 805-832.

Diderichsen, F., T. Evans, et al. (2001). The social basis of disparities in health. Challenging health inequities: from ethics to action. Evans. T., Whitehead. M., Diderichsen. F., Bhuiya. A. and Wirth. M. New York, Oxford University Press.

Esser, I. and J. Palme (2010). "Do public pensions matter for health and wellbeing among retired persons? Basic and income security pensions across 13 Western European countries." International Journal of Social Welfare 19: S103-S120.

Esping-Andersen G. (1990). The three worlds of welfare capitalism. Cambrigde, Polity Press. European Social Survey (2009). "European Social Survey." Retrieved 20101105, from http://www.europeansocialsurvey.org/.

Federico, B., G. Costa, et al. (2007). "Educational inequalities in initiation, cessation, and prevalence of smoking among 3 Italian birth cohorts." Am J Public Health 97(5): 838845.

Ferrarini, T. (2006). Families, states and labour markets : institutions, causes and consequences of family policy in post-war welfare states. Cheltenham, UK :, Edward Elgar.

Ferrarini, T. and A. Z. Duvander (2010). "Earner-Carer Model at the Crossroads: Reforms and Outcomes of Sweden's Family Policy in Comparative Perspective." International Journal of Health Services 40(3): 373-398. 
Ferrarini, T. and T. Norstrom (2010). "Family policy, economic development and infant mortality: a longitudinal comparative analysis." International Journal of Social Welfare 19: S89-S102.

Finch, N. (2008). Family polices in the UK. Family Policies in the Context of Family Change: The Nordic Countries in Comparative Perspective. I. Ostner and C. Schmitt. Hiedelburg, Springer Science.

Fokkema, T. (2002). "Combining a job and children: contrasting the health of married and divorced women in the Netherlands?" Soc Sci Med 54(5): 741-752.

Fritzell, J. and V. M. Ritakallio (2010). "Societal shifts and changed patterns of poverty." International Journal of Social Welfare 19: S25-S41.

Fritzell, S. and B. Burström (2006). "Economic strain and self-rated health among lone and couple mothers in Sweden during the 1990s compared to the 1980s." Health Policy 79(2-3): 253-264.

Fritzell, S., G. Ringback Weitoft, et al. (2007). "From macro to micro: the health of Swedish lone mothers during changing economic and social circumstances." Soc Sci Med 65(12): 2474-2488.

Fritzell, S., A-S. Bakshi, et al. (2011) "Discourses of money and health. A focus groups analysis with Swedish lone mothers with financial difficulties." Manuscript.

Gornick, J. C. and M. K. Meyers (2003). Families that work : policies for reconciling parenthood and employment. New York, N.Y., Russell Sage Foundation.

Graham, H. (2007). Unequal lives : health and socioeconomic inequalities. Maidenhead, Open University Press.

Grant, L. (2009). "Women's disconnection from local labour markets: Real lives and policy faliure." Critical Social Policy 29(3): 330-350.

Gregg, P., S. Harkness, et al. (2009). "Welfare reform and lone parents in the UK." Economic Journal 119(535): 38-65.

Hope, S., C. Power, et al. (1999). "Does financial hardship account for elevated psychological distress in lone mothers?" Social Science \& Medicine 49(12): 1637-1649.

Huber, E., J. D. Stephens, et al. (2009). "The Politics of Women's Economic Independence." Soc Pol: jxp005.

Istat (2002). Le condizioni di salute della popolazione. Indagine Multiscopo sulle famiglie. Condizioni di salute e ricorso ai servizi sanitari. Anni 1999-2000. Roma, Instituto nazionale di statistica.

Istat (2007). Condizioni di salute, fattori di rischio e ricorso ai servizi santari. Statistiche in breve, Istat.

Istat (2008). Evoluzione e nuove tendenze dell instabilità coniugale. Roma.

Jarvis, M. J. and J. Wardle (2006). Social patterning of individual health behaviours: the case of cigarette smoking. Social determinants of health. M. Marmot and R. Wilkinson. New York, Oxford University Press: 224-237.

Jusot, F., M. Khlat, et al. (2008). "Job loss from poor health, smoking and obesity: a national prospective survey in France." J Epidemiol Community Health 62(4): 332-337.

Jylhä, M., J. M. Guralnik, et al. (1998). "Is Self-Rated Health Comparable across Cultures and Genders?" The Journals of Gerontology Series B: Psychological Sciences and Social Sciences 53B(3): S144-S152.

Jylhä, M. (2009). "What is self-rated health and why does it predict mortaliy? Towards a unified conceptual model." Soc Sci Med 69: 307-316.

Korpi, W. (2000). "Faces of Inequality: Gender, Class, and Patterns of Inequalities in Different Types of Welfare States." Social Politics: International Studies in Gender, State \& Society 7(2): 127-191. 
Korpi, W., T. Ferrarini (2011). "Women's opportunities under different constellations of family policies in western countries: inequality tradeoff re-examined." Working paper series. Swedich Institute for Social Research. Stockholm University. No 2/2011. Downloadable from: http://swopec.hhs.se/sofiwp/abs/sofiwp2011_002.htm (2011-0616)

La Valle, I., E. Clery, et al. (2008). Maternity rights and mothers' employment decisions. London.

Lahelma, E., S. Arber, et al. (2002). "Multiple roles and health among British and Finnish women: the influence of socioeconomic circumstances." Soc Sci Med 54(5): 727-740.

Lahelma, E. and O. Lundberg (2009). "Health inequalities in European welfare states." European Journal of Public Health 19(5): 445-446.

LaValle, I. and R. Smith (2009). Good quality childcare for all? Progress towards universal provision, National Institute Economic Review. 207: 75-82.

Lewis, J., T. Knijn, et al. (2008). "Patterns of Development in Work/Family Reconciliation Policies for Parents in France, Germany, the Netherlands, and the UK in the 2000s." Social Politics: International Studies in Gender, State and Society 15(3): 261-286.

Lewis, J. (2009) Work-family balance, gender and policy. Cheltenham, UK, Edward Elgar.

LIS Inequality and Poverty Key Figures, http://www.lisdatacenter.org (2010-09-10). Luxembourg: LIS.

Lorant, V., S. Demarest, et al. (2007). "Survey error in measuring socio-economic risk factors of health status: a comparison of a survey and a census." Int J Epidemiol 36(6): 12921299.

Lundberg, M., P. Fredlund, et al. (1996). "A SAS program calculating three measures of interaction with confidence intervals." Epidemiology 7(6): 655-656.

Lundberg, O., M. Åberg Yngwe, et al. (2008). The Nordic experience : welfare states and public health (NEWS). Stockholm, Centre for Health Equity Studies (CHESS), Stockholm University/Karolinska institutet.

Lundberg, O. and K. Manderbacka (1996). "Assessing reliability of a measure of self-rated health." Scandinavian Journal of Public Health 24(3): 218-224.

Lundberg, O., K. Manderbacka, et al. (2000). Health measures in a comparative perspective. Self-rated health in a European perspective. P. M. Nilsson and K. Orth-Gomér. Stockholm, Forskningsrådsnämnden (FRN); 2000:2.

Marmot, M. (2006) Introduction. Social determinants of health. M. Marmot and R. Wilkinson. New York, Oxford University Press: 1-5.

Naldini, M. and C. Saraceno (2008). "Social and Family Policies in Italy: Not Totally Frozen but Far from Structural Reforms." Social Policy \& Administration 42(7): 733-748.

Nordenmark, M., M. Strandh, et al. (2006). "The impact of unemployment benefit system om mental wellbeing of the unemployed in Sweden, Ireland and Great Britain." European Societies 8(1): 83-110.

Office for National Statistics (2002). General Household Survey: Living in Britain 2001. London, Office for National Statistics.

Orloff, A. S. (1993). "Gender and the social rights of citizenship: the comparative analysis of gender relations and welfare states." American Sociological Review 58,3(June).

Orloff, A. S. (2002). Women's Employment and Welfare Regimes. Globalization, Export Orientation and social policy in Europe and North America. Programme paper Number 12

Reid, C. and A. Tom (2006). "Poor Women's Discourses of Legitimacy, Poverty and Health".Gender \& Society 20(3): 402-421.

Rothman, K. J. and S. Greenland (1998). Modern epidemiology. Philadelphia, LippincottRaven. 
Sabbadini, L. (2006). Madri sole. Profili e tempi di vita in Italia. Madri sole e nuove famiglie. Declinazioni inattese della genitorialita. F. Bimbi and R. Trifiletti. Roma, Edizioni Lavoro: $37-54$.

Sen, A. (2000)."Social exclusion: Concept, application, and scrutiny." Asian Development Bank. Social Development Papers No. 1. Downloadable from: http://www.adb.org/documents/books/social_exclusion/Social_exclusion.pdf (201106-16)

Solera, C. (1998). Income Transfers and Support for Mothers' Employment: The Link to Family Poverty Risks. A comparison between Italy, Sweden and the UK.

Statistics Sweden (2006). The Swedish survey of living conditions. Supplement to Appendix 16, Statistics Sweden. 2009.

Trifiletti, R., A. Pratesi, et al. (2001). Care arrangements in single parent families. . National Report: Italy SOCCARE Project Report 2.3

UNESCO (1997) International Standard Classification of Education I S C E D 1997. Retrieved 20110610, from: http://www.unesco.org/education/information/nfsunesco/doc/isced_1997.htm

Waldron, I. and D. Lye (1989). "Employment, unemployment, occupation, and smoking." Am J Prev Med 5(3): 142-149.

Yngwe, M. Å., F. Diderichsen, et al. (2001). "The role of income differences in explaining social inequalities in self rated health in Sweden and Britain." Journal of Epidemiology and Community Health 55(8): 556-561.

Zabkiewicz, D. (2010). "The mental health benefits of work: do they apply to poor single mothers?" Social Psychiatry and Psychiatric Epidemiology 45(1): 77-87. 


\section{Does non-employment contribute to the health disadvantage among lone mothers in Britain, Italy and Sweden? Synergy effects and the meaning of family policy}

Authors: Sara Fritzell ${ }_{a}$, Francesca Vannoni $b_{b}$, Margaret Whitehead $d_{c}, B_{0}$ Burström $_{d}$, Giuseppe Costa, ${\text { Stephen } \text { Clayton }_{\mathrm{f}} \text {, Johan Fritzell }}_{\mathrm{g}}$

a Department of Public Health Sciences, Division of Social Medicine, Karolinska Institute, 171 76, Stockholm, Sweden

Email: sara.fritzell@ki.se

Tel: 0046852480178 / 0046704055107

bItalian National Institute of Statistics, Piedmont regional office, Turin, Italy (the paper reflects the author's personal opinions and does not involve the Italian National Institute of Statistics)

Email: francesca.vannoni@epi.piemonte.it

cDivision of Public Health, University of Liverpool, Liverpool L69 3GB, United Kingdom Email: mmw@liverpool.ac.uk

${ }_{d}$ Department of Public Health Sciences, Division of Social Medicine, Karolinska Institute, 171 76, Stockholm, Sweden

Email: bo.burstrom@ki.se

eDept. of Clinical and Biological Sciences, University of Turin, Via Sabaudia 164, 10095 Grugliasco, Italy

Email: giuseppe.costa@epi.piemonte.it

fDivision of Public Health, University of Liverpool, Liverpool L69 3GB, United Kingdom Email: Stephen.Clayton@liverpool.ac.uk

${ }_{\mathrm{g}} \mathrm{CHESS}$, Centre for Health Equity Studies, Stockholm University/Karolinska Institute, 10691 Stockholm, Sweden

And Institute for Futures Studies, Box 591, 10131 Stockholm, Sweden

Email: johan.fritzell@chess.su.se 
Table I. Social characteristics of lone vs couple mothers, aged 25-59, by employment status in Britain (2000-2003), Italy (2000 and 2005) and Sweden (2000-2005)

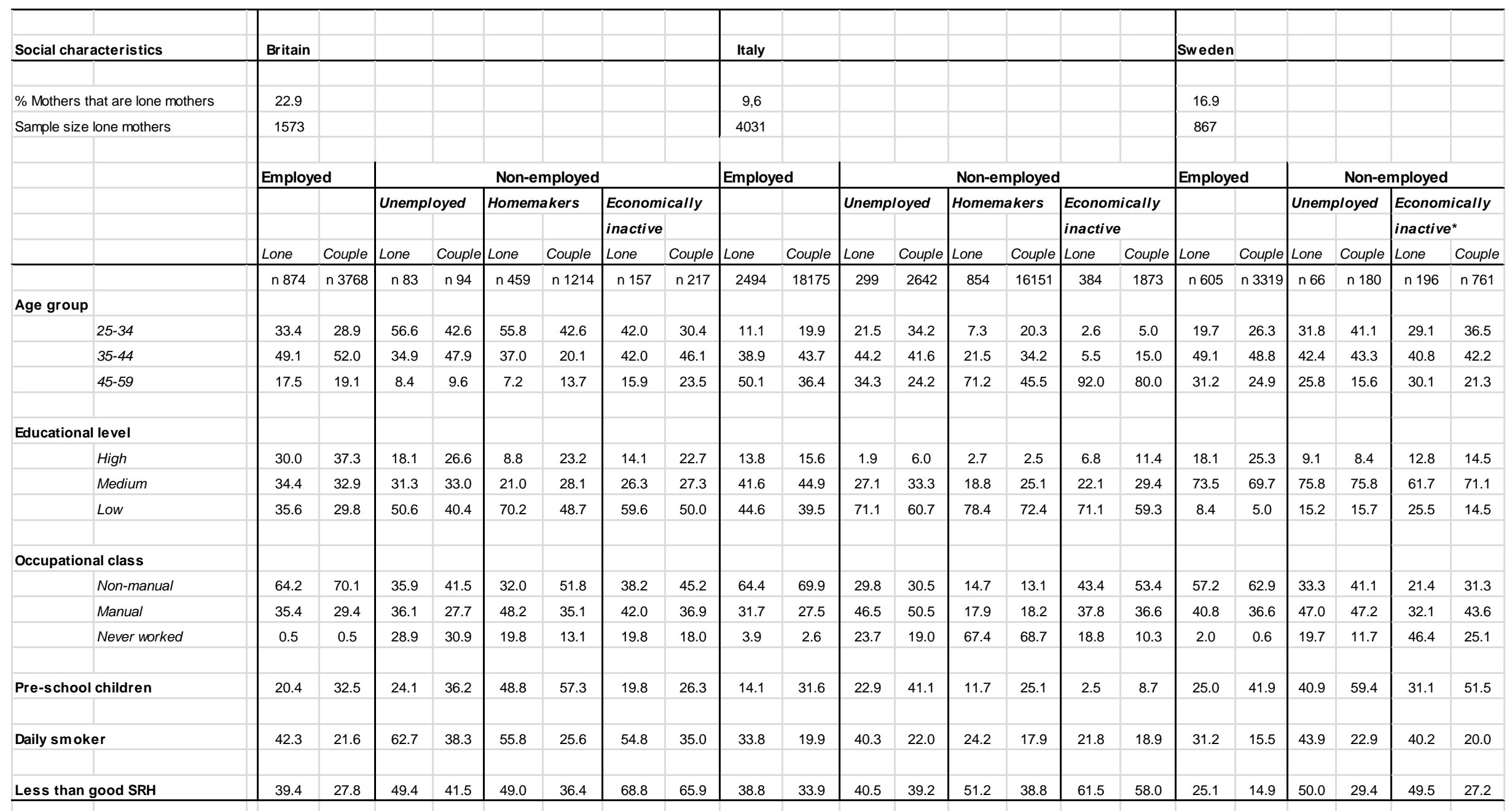

*including homemakers 
Table II. Odds ratios for poor health for lone mothers compared to couple mothers aged 25-59 with 95\% Cl. Data from Britain (2000-2003), Italy (2000 and 2005) and Sweden (2000-2005)

\begin{tabular}{|c|c|c|c|c|c|c|c|c|c|c|c|c|c|c|c|}
\hline & Britain & & & & & Italy & & & & & Sweden & & & & \\
\hline & Model $1^{*}$ & Model $2^{\text {t* }}$ & Model $3^{\star \star \star}$ & Model $4^{\star \star \star \star}$ & Model $5^{\star \star \star \star \star}$ & Model $1^{*}$ & Model $2^{\text {t* }}$ & Model $3^{\star \star \star *}$ & Model $4^{\star \star \star \star}$ & Model $5^{\star \star \star \star \star}$ & Model $1^{\star}$ & Model $2^{\star \star *}$ & Model $3^{* \star \star}$ & Model $4^{\star \star \star \star}$ & Model $5^{\star \star \star \star \star \star ~}$ \\
\hline Couple mother & 1.0 & 1.0 & 1.0 & 1.0 & 1.0 & 1.0 & 1.0 & 1.0 & 1.0 & 1.0 & 1.0 & 1.0 & 1.0 & 1.0 & 1.0 \\
\hline
\end{tabular}

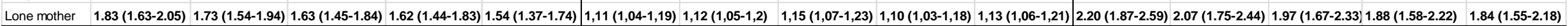

*adjusted for age group

**adjusted for age group and level of education

*** adjusted for age group, level of education and non-employment

**** adjusted for age group, level of education and daily smoking

*****adjusted for age group, level of education, daily smoking and non-employment 
Table III. Evaluation of synergy effects between lone motherhood and non-employment on self-rated health for mothers aged 25-59 years (adjusted for age and level of education). Data from Britain (2000-2003), Italy (2000 and 2005) and Sweden (2000-2005)

\begin{tabular}{|c|c|c|c|c|c|c|c|}
\hline \multirow[b]{2}{*}{ Britain } & \multirow[b]{2}{*}{ Lone motherhood } & \multirow{2}{*}{\begin{tabular}{|l} 
Non-employed* \\
Yes \\
\end{tabular}} & \multirow[b]{2}{*}{ No } & \multicolumn{2}{|c|}{ Economically inactive ** } & \multirow{2}{*}{$\begin{array}{l}\text { Unemployed } \\
\text { Yes } \\
\end{array}$} & \multirow[b]{2}{*}{ No } \\
\hline & & & & Yes & No & & \\
\hline & Yes & $2.74(2.31-3.26)$ & $1.66(1.42-1.94)$ & $2.79(2.33-3.34)$ & $1.66(1.42-1.94)$ & $2.36(1.52-3.67)$ & $1.66(1.42-1.93)$ \\
\hline & No & $1.72(1.51-1.95)$ & 1 & $1.71(1.50-1.95)$ & 1 & $1.79(1.18-2.72)$ & 1 \\
\hline & Synergy index & $1.27(0.92-1.75)$ & & $1.30(0.93-1.82)$ & & $0.94(0.38-2.36)$ & \\
\hline & $\mathrm{n}$ & \multicolumn{2}{|c|}{6866 (employed+all not employed) } & \multicolumn{2}{|c|}{6689 (employed+economically inactive) } & \multicolumn{2}{|c|}{4819 (employed+ unemployed) } \\
\hline \multirow[t]{5}{*}{ Italy } & Lone motherhood & & & & & & \\
\hline & Yes & $1.41(1.27-1.57)$ & $1.07(0.98-1.17)$ & $1.45(1.29-1.64)$ & $1.07(0.98-1.16)$ & $1.21(0.95-1.53)$ & $1.09(1.00-1.19)$ \\
\hline & No & $1.11(1.06-1.16)$ & & $1.08(1.03-1.13)$ & & $1.32(1.21-1.45)$ & \\
\hline & Synergy index & $2.25(1.14-4.42)$ & & $3.04(1.35-6.83)$ & & $0.50(0.12-2.04)$ & \\
\hline & $n$ & \multicolumn{2}{|c|}{42872 ( employed+all not employed) } & \multicolumn{2}{|c|}{39931 (employed+economically inactive) } & \multicolumn{2}{|c|}{23610 (employed+ unemployed) } \\
\hline \multirow[t]{5}{*}{ Sweden } & Lone motherhood & & & & & & \\
\hline & Yes & $5.00(3.80-6.47)$ & $1.79(1.46-2.21)$ & $4.82(3.56-6.53)$ & $1.80(1.46-2.22)$ & $5.39(3.28-8.87)$ & $1.80(1.46-2.22)$ \\
\hline & No & $2.07(1.74-2.47)$ & 1 & $2.02(1.67-3.44)$ & 1 & $2.33(1.66-3.28)$ & 1 \\
\hline & Synergy index & $2.12(1.42-3.16)$ & & $2.10(1.34-3.29)$ & & $2.23(1.01-4.22)$ & \\
\hline & $\mathbf{n}$ & \multicolumn{2}{|c|}{5127 (employed+all not employed) } & \multicolumn{2}{|c|}{4881 (employed+economically inactive) } & \multicolumn{2}{|c|}{4170 (employed+ unemployed) } \\
\hline \multicolumn{8}{|c|}{ *All categories that are not employed } \\
\hline ** All eco & omically inactive inc & ding homemakers & & & & & \\
\hline
\end{tabular}




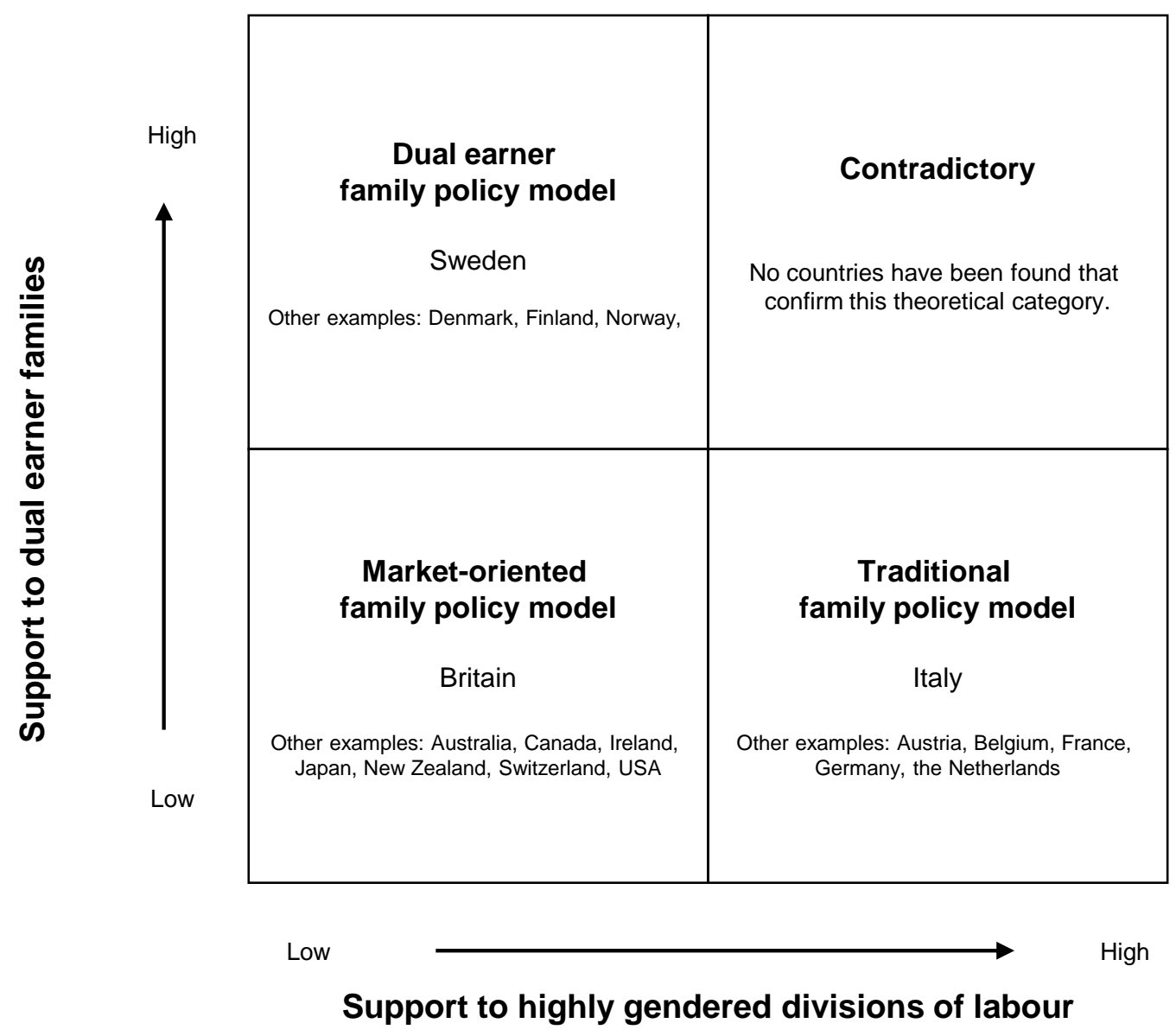

